\title{
GEO-EYE
}

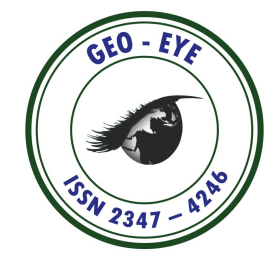

RESEARCH ARTICLE

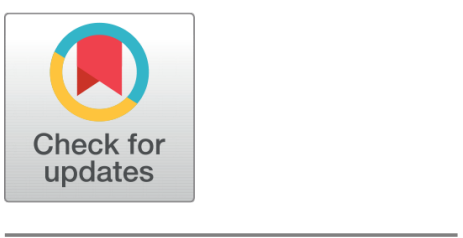

G OPEN ACCESS

Received: 11.12.2019

Accepted: 24.05 .2020

Published: 12.06.2020

Citation: Shiva Kumar R. (2020). FATAL ROAD TRAFFIC ACCIDENTS IN MYSORE CITY USING

GEOGRAPHICAL INFORMATION

SYSTEM . Geo-Eye. 9(1): 1-3. https://

doi.org/10.53989/bu.ge.v9i1.1

Funding: None

Competing Interests: None

Copyright: (c) 2020 Shiva Kumar. This is an open access article distributed under the terms of the Creative Commons Attribution License, which permits unrestricted use, distribution, and reproduction in any medium, provided the original author and source are credited.

Published By Bangalore University, Bengaluru, Karnataka

ISSN

Print: 2347-4246

Electronic: $X X X X-X X X X$

\section{FATAL ROAD TRAFFIC ACCIDENTS IN MYSORE CITY USING GEOGRAPHICAL INFORMATION SYSTEM}

\author{
R Shiva Kumar ${ }^{1}$ \\ 1 Guest Faculty, Department of Geography, Jnanabharathi Campus, Bangalore University, \\ Bengaluru
}

\begin{abstract}
A deep study of road traffic deaths during 2013 was conducted in Mysore city, Karnataka, India. Victims in RTAs sustain varieties of injuries, which are fatal or dangerous to life. The current paper has attempted to mapping the fatal road traffic accidents within Mysore City in the year of 2013. This is a descriptive secondary data analysis of police records of reported RTA of the year January-December 2013 collected from Krishnaraja, Devaraja, and Narasimaraja Traffic police stations within the administrative region of Mysore city. During the one-year study period of Mysore city in 2013 occurs 902 cases of road traffic accidents. within Mysore city there are 141 death road traffic accident has plotted using Arc Gis 10.3 software. Mainly the result shows that in the city center, North-West of the city and state Highway 88 have more death road traffic accidents. In adding, an effort also made to know the percentage of cause of death.
\end{abstract}

Keywords: Fatal accidents; Road traffic accidents; GIS

\section{Introduction}

Road Traffic Accident is any vehicular accident happening on the roadway i.e. initiating on, involving a vehicle partially on the roadway. Road traffic injuries are one of the important reasons of death in the world. This includes collision of an automobile with a, rider / pillion rider / driver / passengers/pedestrian or another automobile or with a non-automobile on the roadway or fall from a moving vehicle causing injuries or death of the individuals is involved (Kumar D.R.,2013). Road traffic grievances are a major but neglected public health challenge that requires intensive efforts for effective and sustainable prevention. Of all the systems with which people have to deal every day, road traffic systems are the most complex and the most dangerous.

Worldwide, an estimated 1.2 million people are killed in road crashes each year and as many as $\mathbf{5 0}$ million are injured. Road traffic injuries are the eighth foremost cause of death for all age groups. More than half of all road traffic deaths are among vulnerable road users: pedestrians, cyclists, and motorcyclists. Road traffic injuries are now the foremost cause of death for children and young adults aged 5 to 29 years. The number of deaths on the world's roads remains unsatisfactorily high, with an assessed 1.35 million people dying each year (WHO.2018). Drivers' fault accounted for $78 \%$ of total accidents, $76.5 \%$ of total injuries, and $73.7 \%$ of total fatalities in 2013 (Singh S.K $.2017)$. 
The continues to be a strong association between the risk of a road traffic death and the income level of countries. With an average rate of 27.5 deaths per 100,000 population, the risk of a road traffic death is more than 3 times higher in low-income countries than in high-income countries where the average rate is 8.3 deaths per 100,000 population (WHOGlobal Status Report on Road Safety 2018). Mysore city now way days attraction of more tourism, job opportunity, and peaceful city, causes no of vehicles travels arrived city hugely, many of the vehicle users' negligence, drink, and drive, over speeds causes road traffic accident leads injuries and death.

\section{Study area}

Mysore is most tourism magnetism palace city and second largest city in the state of Karnataka. Mysore is located $135 \mathrm{~km}$ from Bangalore, the state capital. It is the headquarters of the Mysore district and the Mysore division and lies about $146 \mathrm{~km}$ (91 mi) southwest of Bangalore, the capital of the state. The city is spread across an area of 128.42 sq.km (50 sq mi) and is situated at the base of the Chamundi Hills. Mysore is located at $76^{\circ} 39^{\prime} \mathrm{E}$ and $76^{\circ} 42^{\prime} \mathrm{E}$ longitude and $12^{\circ} 18^{\prime} \mathrm{N}$ and $12^{\circ} 30^{\prime} \mathrm{N}$ latitude and has an average altitude of 770 meters $(2,526 \mathrm{ft})$. It is located in the southern region of the state of Karnataka. Mysore city has 65 wards and the total population is $8,85,416$ (census of India, 2011).

The existing two-lane road linking Mysore to the state capital Bangalore has been upgraded to a four-lane highway. This has reduced the travel time significantly. National Highway 212, and State Highways 17, 33, 88 passes through Mysore connecting it to nearby cities.

\section{Methodology}

Toposheet surveyed 2005-06 and satellite images from Google Earth databases were used to digitize road networks in Mysore city. The secondary data of 2013 were also collected relating to accidents registered with Krishnaraja, Devaraja and Narasimaraja Traffic Police stations in Mysore city. The occurrences of accidents death location were plotted using ArcGIS 10.3 software.

\section{Result and Discussion}

The accidents occur due to several factors. However, an accident's severity may even lead to the death of the occupants. The locations of accidents that resulted in the death of the passengers in Mysore City in the year 2013 are shown in Figure 1.

The month-wise accidents resulting in deaths have been presented in table 1 The corresponding Figure 2 shows that January, May, and July in the year 2013 have recorded the highest number of deaths and the month of March, November, and December have a comparatively lower rate of

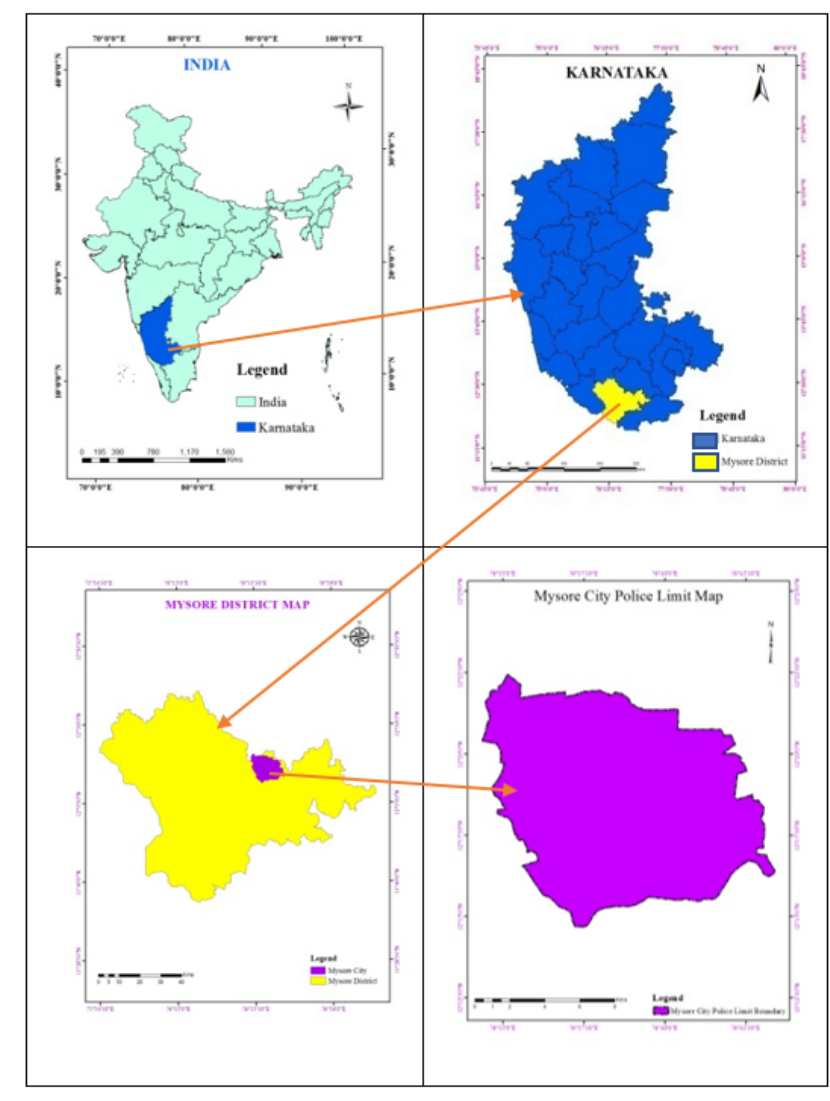

Fig. 1. Study area map

Table 1. Month-wise details of the number of death by accidents

\begin{tabular}{lll}
\hline Sl.No. & Month & Number of Deaths \\
\hline 1 & January & 16 \\
2 & February & 14 \\
3 & March & 6 \\
4 & April & 14 \\
5 & May & 16 \\
6 & June & 13 \\
7 & July & 16 \\
8 & August & 10 \\
9 & September & 12 \\
10 & October & 10 \\
11 & November & 8 \\
12 & December & 6 \\
Total & & $\mathbf{1 4 1}$ \\
\hline
\end{tabular}

Source: Traffic Police Stations 


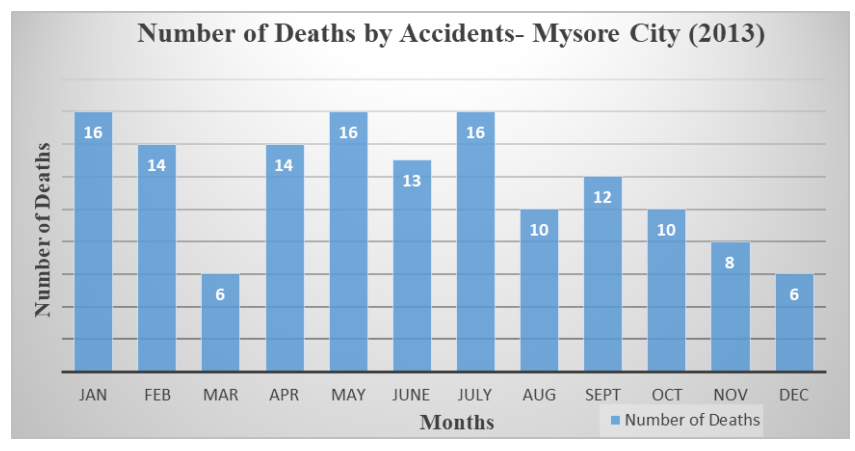

Fig. 2. Number of deaths by accidents in Mysore city (2013)

deaths. Figure 3 shows the location of 141 people who died in the year 2013 at 132 locations across the City out of which 120 were male passengers and 21 were female passengers. The majority of these accidents were found to have occurred in the central part of the City and at various junctions in the state highways.

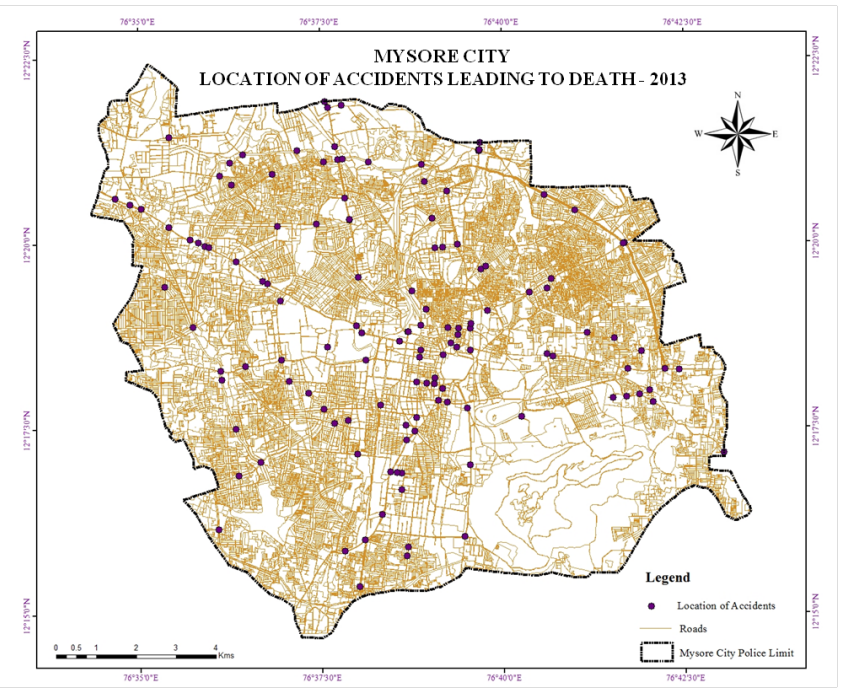

Fig. 3. Death by accidents in Mysore city in the year 2013

The main reasons for these severe accidents to result in the death of the passengers were due to alcohol consumption while driving and the improper crossing of the pedestrians. In the year 2013, almost 48 pedestrians had died due to the accidents mainly due to careless crossings of the road.

\section{Conclusion}

The analysis shows that the distribution of road traffic accidental deaths. Moreover, in Mysore city road traffic accidents deaths are relatively higher in January-February, April-May and July months which shows that extreme negligence of travelers impacts the existence of road traffic accidents. There are several factors responsible for accidents but drivers' fault is the most important factor. Road traffic accidents are growing at an alarming rate, causing the loss of valuable work force and resources. Utmost of them caused by human mistakes, and they can be prevented by providing road safety education to all. Improvement of roads, streetlights and displaying of traffic signs needed.

\section{References}

1) Singh S. Road Traffic Accidents in India: Issues and Challenges. 2017. doi:10.1016/j.trpro.2017.05.484.

2) Kual A, Sinha US, Pathak YK, Singh A, Dehradoon JG, Kapoor AK, et al. Fatal Road Traffic Accidents, Study of Distribution, Nature And Type Of Injury. JIAFM. 2005;27(2).

3) Roberts SE, Nielsen D, owski AK, Jaremin B. Fatal accidents and injuries among merchant seafarers worldwide. Occupational Medicine. 2014;64(4):259-266. Available from: https://dx.doi.org/10. 1093/occmed/kqu017.

4) Kumar CAS, Junaidi KA. Deaths due to fatal road traffic accidents in Kalabuargi District a retrospective study. Indian Journal of Forensic Medicine \& Toxicology. 2013;12(4):25-25.

5) Singh HH, Aggarwal AD. Fatal road traffic accidents among young children. J Indian Acad Forensic Med. 2010;32(4).

6) Kumar NB, Ghormade PS, Tingne CV, Keoliya AN. Trends of Fatal Road Traffic Accidents In Central India. Journal of Forensic Medicine. 2013;22(2).

7) Nasiri N, Nazari P, Kamali A, Sharifi A, Sharifi H. Factors contributing to fatal road traffic accidents in the South of Kerman during the period from 2013 to 2017, Iran. Journal of Occupational Health and Epidemiology. 2013;8(1):6-11.

8) Lotfi $\mathrm{MH}$, Lashkardoost $\mathrm{H}$, Hamedi A. Fatal road traffic accidents in Yazd province. Journal of Emergency Practice and Trauma. 2011;5(2):5155.

9) Seyni SB, Seyni ZA, AW M, Foumakoye RS, Abassi A. Fatal Road Traffic Accidents in Niamey about 133 Cases of Death. Surgery Current Research. 2017;07(01). Available from: https://dx.doi.org/10.4172/21611076.1000286

10) Kar S, Das SC, Tiwari A, Pharveen I. Pattern of Road Traffic Accidents in Bhubaneswar, Odisha. Clinical Epidemiology and Global Health. 2016;4(3):115-119. Available from: https://dx.doi.org/10.1016/j.cegh. 2015.07.003.

11) Sonawane $T$, Bhamare $S$, Nivangune PMK. Analysis of Road Fatal Accidents. IJARCCE. 2018;7(11):97-99. Available from: https://dx.doi. org/10.17148/ijarcce.2018.71120.

12) World Health Organization 2018. STATUS REPORT ON ROAD SAFETY. 2018. 